\title{
PARAMETERS OF INTENSITY DISTRIBUTION IN THE IZMIT AND DUZCE (TURKEY) EARTHQUAKES
}

\author{
E. L. LEKKAS ${ }^{1}$
}

\section{ABSTRACT}

On $17^{\text {th }}$ August and $12^{\text {th }}$ November 1999 the wider area of Izmit, Adapazari, Dózce and Bolu (Turkey) was hit by two seismic shocks with magnitude $\mathrm{M}_{\mathrm{w}}=7.4$ and $\mathrm{M}_{\mathrm{w}}=7.1$, respectively. The earthquakes produced surface ruptures over a distance of at least $150 \mathrm{~km}$, as well as settlement, soil fissures, liquefaction, landslides, tsunamis and subsidence. Damage and intensity evaluation followed the EMS ${ }_{1992}$ and EMS ${ }_{1998}$. The maximum intensities approached XII in both earthquakes. Intensity maps show alignment parallel to the strike of the seismic faults, with local variations due to geometry and kinematics of certain tectonic structures. Intensities were considerably amplified locally by concomitant geodynamic phenomena.

KEY WORDS: EMS-1998, earthquake, Turkey, tectonic, site effect

\section{INTRODUCTION}

On 17 August, 03:01:37 local time, a severe earthquake occurred, with an epicenter at the southwestern suburbs of Izmit town in Turkey. The earthquake magnitude was $M_{w}=7,4$ and the seismic source depth was estimated at 15-17 km. Extensive damage was recorded along an E-W zone of about $100 \mathrm{~km}$ in length that includes the towns of Adapazari, Izmit, Gylcók and Yalova. Heavy damage was also reported farther away, as in Istanbul, Bursa, Eskisehir, Dózce, Bolu (Figure 1).

Almost three months later, on $12^{\text {th }}$ November 1999, 19:57:21 local time another severe seismic event of magnitude $M_{w}=7.1$ took place with epicentre about $90 \mathrm{~km}$ to the east of the former. The earthquake caused significant damage along an E-W zone about $70 \mathrm{~km}$ long, which included Adapazari, Hendek, Dózce, Kaynasli, Bolu and other population centres (Figure 1).

The surficial expression of the seismic fault and the manifestation of concomitant geodynamic effects largely contributed to the damage at both events. The effects included soil fissures, liquefaction, landslides, settlement, lateral spreading, coastline changes, tsunamis, and so on, as well as fires (LEKKAS et al., 1999). Additionally, tectonic structures related to strike-slip deformation, such as pull apart basins, oversteps, en echelon arranged fractures and so on, as well as the local geotechnical conditions and construction type, all played a part in the manifestation and extent of damage.

The purpose of this paper is to determine the parameters that contributed qualitatively and quantitatively to damage manifestation and intensity distribution during the earthquakes of $17^{\text {th }}$ August and $12^{\text {th }}$ November 1999. The results come from both field observations and data elaboration at the laboratory.

\section{SEISMIC FAULTS}

The $17^{\text {th }}$ August 1999 earthquake was centered in the outskirts of Izmit town. The earthquake was the result of the reactivation of the North Anatolian Fault Zone, and particularly of a portion of it that was dormant in previous seismic events of the $20^{\text {th }}$ century (STEIN et al., 1997). Before the earthquake, repeated GPS surveys indicated an average creep displacement of 10-15 mm in this portion of the fault zone (ARMIJO et al., 1999, STRAUB et al., 1997). Instrumental data indicate that the fault plane was almost vertical striking E-W with a right-lateral strike-slip movement.

Field observations show that the surficial rupture was more than $90 \mathrm{~km}$ long (LEKKAS et al., 1999), vertical with right-lateral displacement in excess of 5 meters, in good agreement with the instrumental data (Figure 1). This seismic fault extends into the submarine area of Marmara bay and west of Gylcók.

The $12^{\text {th }}$ November 1999 earthquake, the epicenter of which was south of Dózce, occurred at the eastern end of the previously activated segment of the NAFZ (Figure 1). Also, this section remained dormant in other

1. Dept. of Geology, Panepistimioupoli, 15784 Athens, Greece 


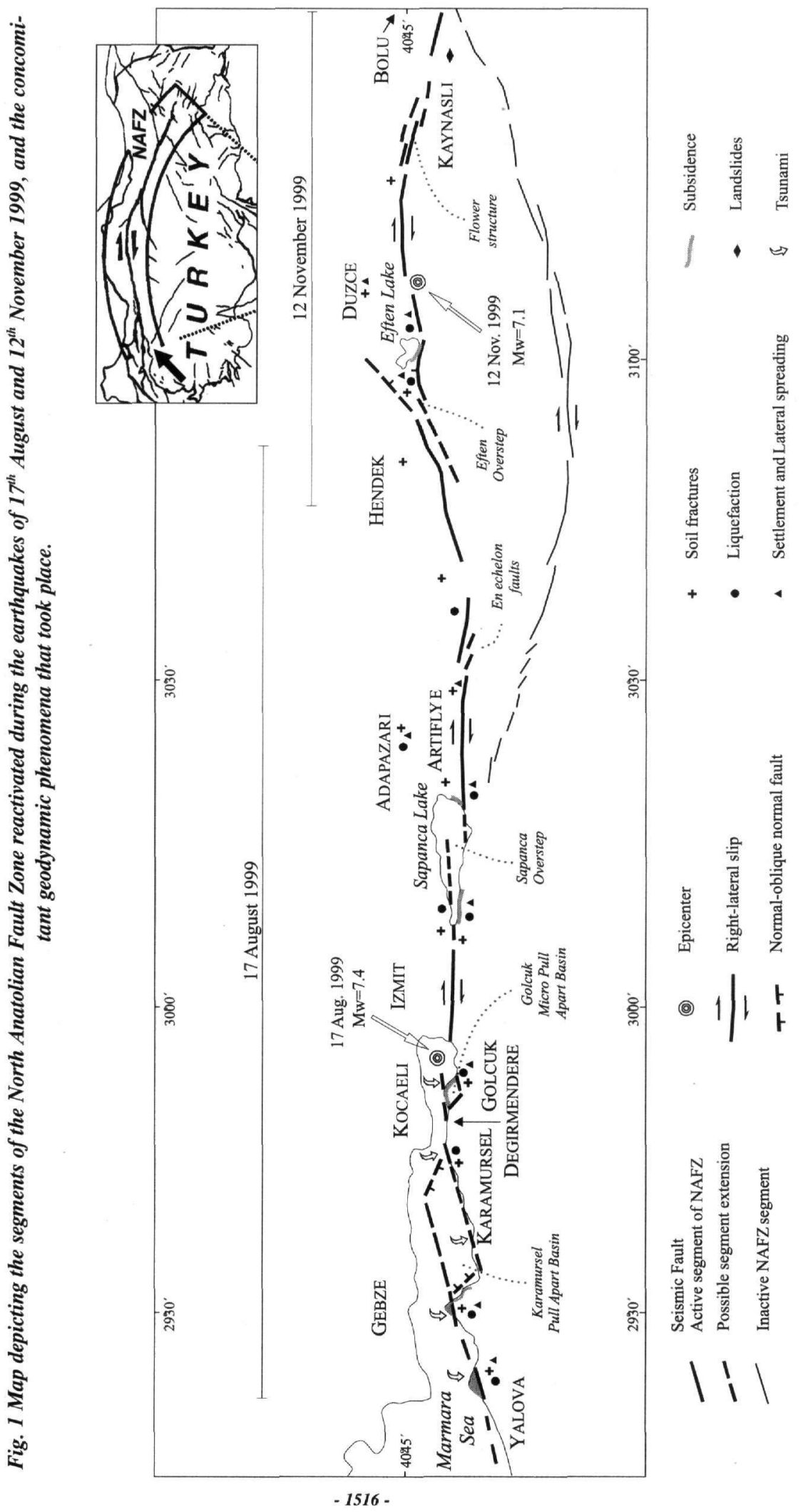


earthquakes of our century. Instrumental data show that the fault plane is almost vertical, strikes E-W and is characterized by a right-lateral slip. Field data showed that the seismic rupture surface is vertical and more than $40 \mathrm{~km}$ long and the horizontal offset locally exceeded 4.5 meters.

The two activated fault segments of the NAFZ caused impressive displacements of rows of trees, fences, roads, pavements and canals, which allowed determination of the geometric and kinematic characteristics of the seismic fault on each section of it. The geometry and kinematics varied locally along the deformation zone; these local variations are attributed to the mode of fracture, the stress field and the occurrence of heterogeneous media -particularly the differential performance of geological formations.

Such variations usually appear along strike-slip faults and are strongly related to oversteps, en echelon structures, flower structures, micro (a few tens of $\mathrm{m}$ ) and macro (several hundreds of $\mathrm{m}$ to a few $\mathrm{km}$ ) pull-apart basins (AYDIN \& NUR 1982, HARDING 1985, LADE \& COLE 1984, MANN et al., 1983, and others) and are held responsible for local differentiation in damage manifestation and intensity distribution (Figs. 1,2).

\section{CONCOMITANT GEODYNAMIC PHENOMENA}

During the earthquakes of $17^{\text {th }}$ August and $12^{\text {th }}$ November 1999 a number of geodynamic phenomena (LEKKAS et al., 1999) took place in the broader epicentral area (Figure 1). These phenomena are not only of academic interest, as they aggravated the impact, amplified the intensities, and contributed to intensity differentiation from place to place either in the meizoseismal area or at longer distances. These effects are briefly described below:

- Soil fissures. Soil fissures were reported in many places that loose recent sediments occur. The most characteristic ones were described around Sapanca lake, along the coastal zone among G甲lcók, Degirmendere and Yalova, in Dózce and Kaynasli.

- Liquefaction. It was recorded in the plain area around Sapanca lake, in Adapazari, as well as in the coastal

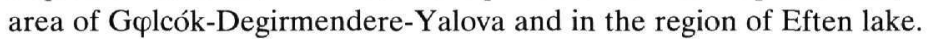

- Landslides. Despite the high magnitude of the $17^{\text {th }}$ August 1999 earthquake, few landslides occurred in the epicentral area. Only few and restricted rockfalls took place along several very steep slopes built of highly fractured rocky formations.

- Settlement. It appeared in many places of the epicentral area, mainly where recent loose formations crop out. Lateral spreading and soil fissures were also present, resulting from the differential settlement of the upper geological strata, as was the case in the neighbouring area of Adapazari and around the lakes of Sapanca and Eften.

- Tsunamis. The $17^{\text {th }}$ August earthquake generated a tidal wave, which affected the coastal region of Marmara

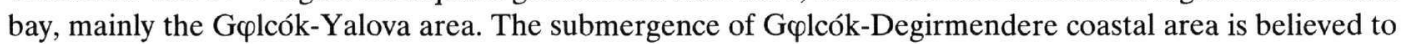
have amplified the influence of the tsunami, the height of which was approximately 4 meters.

- Subsidence. The earthquakes of $17^{\text {th }}$ August and $12^{\text {th }}$ November 1999 produced right-lateral displacements or slip on surface ruptures over a distance of at least $130 \mathrm{~km}$ and were nucleated at a depth of $15-17 \mathrm{~km}$. The fault rupture was very often characterised by en echelon, $R, R^{\prime}$ and $P$ shear structures, and so on. These structures caused subsidence, uplift and rotation on micro and macroscale. The submergence of many coastal areas was the result of pull apart basin formation. The most representative example is the extended subsid-

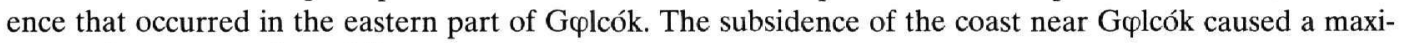
mum submergence about $3.5 \mathrm{~m}$.

The submergence of some regions as well as the manifestation of concomitant geodynamic phenomena are particular cases that aggravated the severity of the earthquake in urban areas. In these cases the augmentation of intensities is not solely or directly attributed to seismic shaking itself.

\section{INTENSITY EVALUATION-GEOGRAPHIC DISTRIBUTION}

Intensity evaluation of the affected area employed the European Macroseismic Scale (EMS-1992) and the updated EMS-1998 (Grónthal, ed. 1993, 1998).

Intensity evaluation was primarily based on damage recordings assessment that contributed to the compilation of an intensity map of the affected area for each seismic event separately $\left(17^{\text {th }}\right.$ August 1999 and $12^{\text {th }}$ November 1999 earthquakes), wherever possible. Additionally, recordings of other effects (not only construction damage) were taken into account in the final evaluation, according to the given guidelines (Grónthal ed. 1993, 1998). 


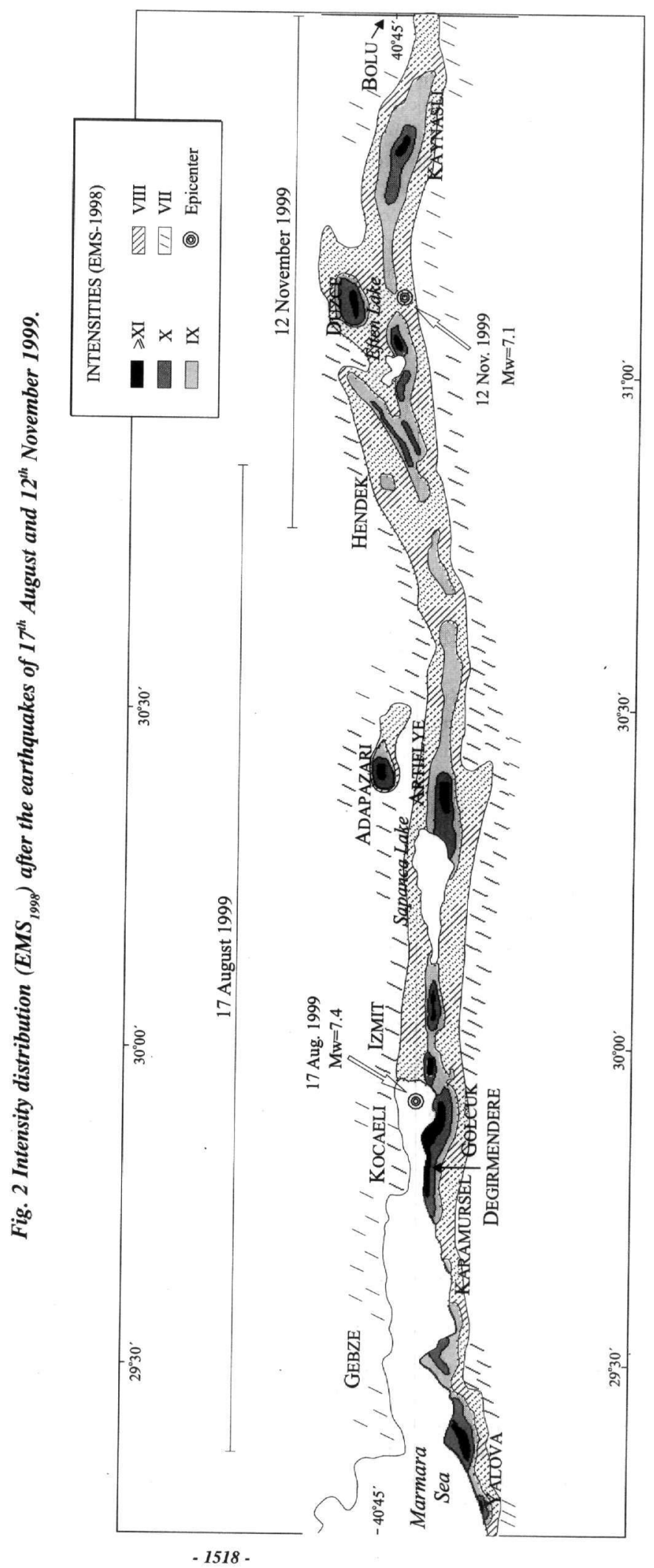


In order to elaborate damage data, areas with dimensions of about $500 \times 500 \mathrm{~m}$ were considered as the basic units, each one corresponding to a few urban blocks. Airphotos and satellite data were indispensable, particularly in areas that were razed and almost all of the buildings collapsed (e.g. Adapazari, Gplcók, Kaynasli).

After evaluation of data recordings, an intensity map was obtained according to the EMS-1998, as depicted in figure 2. The intensity evaluation was done separately for each earthquake, when it was possible. The map shows that:

- The maximum intensities exceeded $\mathrm{I}_{\mathrm{EMS} 98}=\mathrm{XI}$ and locally reached XII (Figure 3) for both seismic events of $17^{\text {th }}$ August and $12^{\text {th }}$ November 1999. During the first earthquake, maximum intensities occurred in the coastal

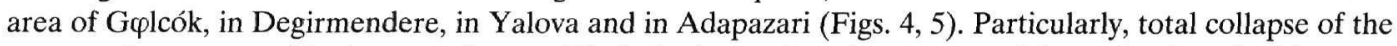
constructions occurred in the coastal area of Gylcók, due to the submergence of the region into the Marmara sea. Constructions were not only affected by seismic loading but also by subsidence, tsunamis, lateral spreading and liquefaction. A similar picture was present in the coastal region of Degirmendere. On the other hand, the situation was better in parts of Yalova, because only liquefaction, soil fissures and lateral spreading took place. Parts of Adapazari town were devastated and all buildings collapsed. These sites were dominated by soil fissures, liquefaction, effects of "sedimentary basin" and "basin edge" effects and so on (Kawase 1996, Lekkas 2000b), which played a significant part in intensity distribution. In Adapazari, tens of buildings sank into the ground, toppled, were partially overturned or collapsed because the soil beneath them liquefied and weakened the foundations (Figure 3). On the contrary, damage was lighter in areas of the town where none of the above phenomena occurred. Intensities that exceeded $\mathrm{I}_{\mathrm{EMS} 98}=\mathrm{XI}$ degree were recorded after the $12^{\text {th }}$ November 1999 earthquake in a portion of Kaynasli, which collapsed thoroughly due to the surface impact of a zone of seismic fissures in the form of a negative flower structure (Lade \& Cole 1984, Harding 1985), and also due to settlement, lateral spreading and liquefaction.

- $\mathrm{I}_{\mathrm{EMS}-98}=\mathrm{X}$ intensities were present in a wider area that formed two elongated zones in both seismic events. Specifically after the $17^{\text {th }}$ August earthquake, $\mathrm{X}$ intensities occurred in an E-W zone that began at Yalova (Figs. 6), was found again at Gylcók, passed through Izmit and stopped in Sapanca lake. The zone reappeared in Adapazari and terminated east of the town. The width of the zone ranged from $100 \mathrm{~m}$ to $200 \mathrm{~m}$. After the $12^{\text {th }}$ November 1999 earthquake, $I_{E M S-98}=X$ contours were arranged in a similar E-W trending zone, which covered the areas of Hendek, Dózce, Kaynasli and was up to $800 \mathrm{~m}$ wide at places. The exact estimation of the intensities that were attributed to the second earthquake was quite hard to make $\left(12^{\text {th }}\right.$ November 1999) in the area between Adapazari-Dózce, because constructions had already been damaged by the earthquake of $17^{\text {th }}$ August 1999. In this case, the cumulative effect of both earthquakes was estimated, incorporating the damage from both earthquakes. In Dózce, about $30 \%$ of the damage is attributed to the first earthquake ( $17^{\text {th }}$ August) and $70 \%$ to the second earthquake $\left(12^{\text {th }}\right.$ November). This estimate regards only the structural elements of reinforced concrete constructions. It was found that the first earthquake exhibited maximum intensities that reached $\mathrm{I}_{\mathrm{EMSys}}=\mathrm{VIII}$ in an E-W zone at Dózce area, while after the second earthquake intensities exceeded $\mathrm{I}_{\mathrm{EMS98}}=\mathrm{X}$ and locally approached XI. This may be attributed to the fact that the resistance of the constructions had already been weakened by the first earthquake.

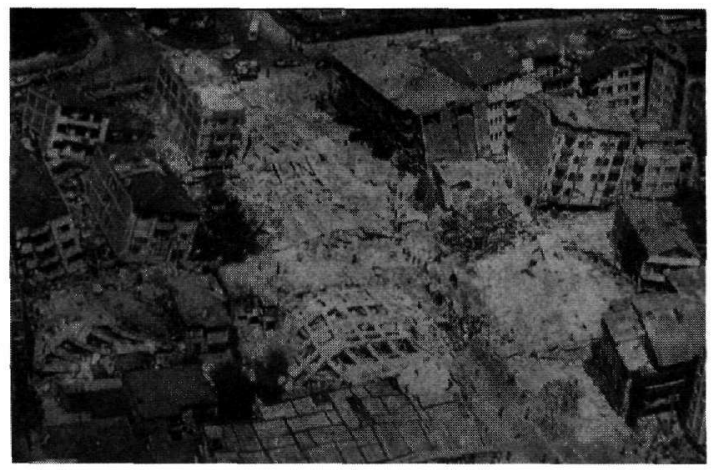

Fig. 3 Representative view of a portion of Adapazari that suffered total damage $\left(I_{E M S-9 s}=X I I\right)$ after the $17^{\text {th }}$ August earthquake.

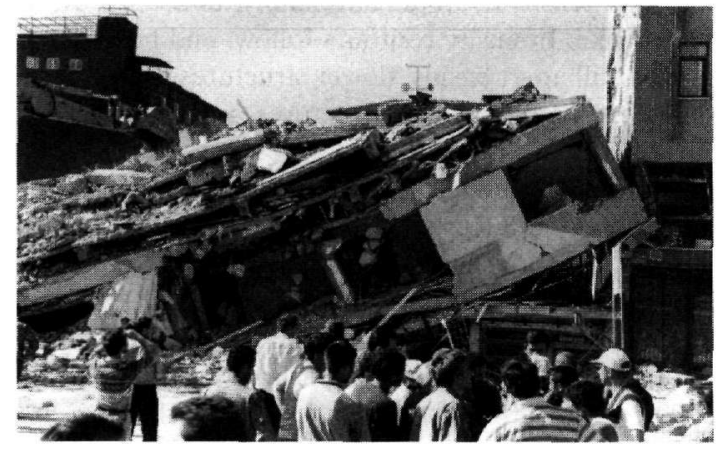

Fig. 4 Reinforced concrete frame structure that collapsed in Gylcók town (damage degree 5). 
- $\mathrm{I}_{\mathrm{EMS}-98}=\mathrm{IX}$ contours covered a wider E-W zone after each earthquake. This intensity zone coincides with the deformation zone, and is wider where pull apart basins, oversteps, flower structures and other strike-slip deformation features occurred.

- $\mathrm{I}_{\mathrm{EMS}-98}=$ VIII intensities also developed in an E-W zone after each earthquake. The arrangement of these intensity contours is not so linear as of the high intensity ones. In this case, intensities seem to have been significantly controlled by site effects or by remarkably poor performance of constructions. More specifically, the distribution of VIII contours depended on the foundation soil response and mainly on the amplification of seismic waves when, for example, loose thin surficial formations overlay the alpine basement. It also depended on the alpine basement geometry that controls the seismic energy propagation.

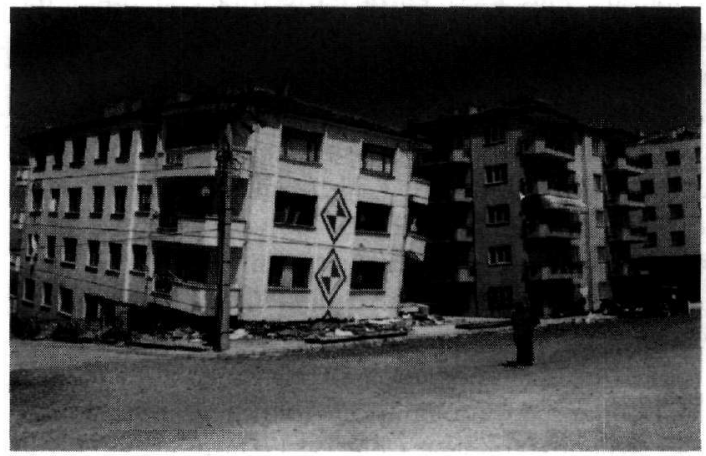

Fig. 5 Reinforced concrete frame structure that sustained collapse of ground floor in the area of Gplcók -Degirmendere (damage degree 5).

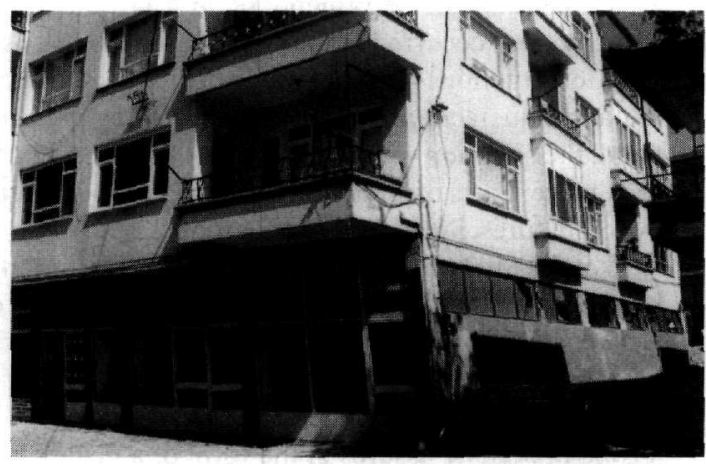

Fig. 6 Reinforced concrete frame structure in Yalova that displayed first story column-hinge deformation, but did not collapse (damage degree 4).

\section{CONCLUSIONS}

The earthquakes of $17^{\text {th }}$ August and $12^{\text {th }}$ November 1999 that hit Turkey and caused thousands of fatalities and widespread damage were attributed to the successive reactivation of two parts of the North Anatolian Fault Zone; these segments had not slipped before in the $20^{\text {th }}$ century. The overall rupture could be traced for a distance of $150 \mathrm{~km}$. The fault rupture was accompanied by pull-apart basins, oversteps, en echelon arranged fractures, flower structures and other strike-slip related features both on a small and large scale.

Damage recording and intensity evaluation were made according to the EMS-1992 and to the updated EMS1998 , soon after both seismic events in the affected area.

Based on already mentioned data, intensities exceeded $\mathrm{I}_{\mathrm{EMS} 98}=\mathrm{XI}$ and even approximated XII in many urban blocks. X intensities occupied extended regions, whereas much wider areas displayed IX and VIII intensities. This was the lower limit of our intensity evaluation, as lower intensities occupied vast areas and the amount of data was overwhelming.

All intensity contours but mainly the $\mathrm{I}_{\mathrm{EMS}-98}{ }^{3} \mathrm{X}$, developed in an E-W orientation, which coincides with the fault strike. Intensity contours follow, and become broader at strike-slip deformation structures as micro- and macro-pull apart basins, flower structures and so forth. On the contrary, when the fault ruptured linearly, without these accompanying structures, intensity contours developed in an E-W elongated zone of significantly small width.

Moreover, intensity distribution directly depended on the concomitant geodynamic phenomena, namely liquefaction, uplift, subsidence, settlement, lateral spreading and so on. Therefore, earthquake vibration was not solely responsible for damage occurrence but it is also the concomitant geodynamic phenomena that must be seriously considered in the future. EMS-1992 and the updated EMS-1998 scales do not incorporate such phenomena due to the rarity of actualistic models.

In the wider area of Adapazari-Dózce that was hit by both earthquakes $\left(17^{\text {th }}\right.$ August and $12^{\text {th }}$ November 1999), it was difficult to assess separately the participation of each seismic event in damage manifestation and, thus, in intensity estimation. Intensity evaluation, in this area was approximated and is based on data and recordings collected mainly after the first earthquake, but also after the second one. So, it is apparent that in this area the recorded intensities do not correspond to the damage caused by the second event only, since the first earthquake had already seriously damaged constructions. 
The recorded intensities were distributed similarly on both fault blocks as a consequence of the predominant horizontal movement of the NAFZ. On the contrary, intensities vary significantly on the two blocks of a rupture in the case of reverse or normal faulting (hanging wall and footwall) (Lekkas, 2000a).

\section{REFERENCES}

ARMIJO, R., MEYER, B., HUBERT, A. \& BARKA, A. 1999. Westward propagation of the North Anatolian fault into the northern Aegean: Timing and kinematics. Geology, 27(3), 267-270.

AYDIN, A. \& NUR, A. 1982. Evolution of pull-apart basins and their scale independence. Tectonics, 1, 91-105.

GRÜNTHAL, G. ed. 1993. European Macroseismic Scale 1992 (up-dated MSK-scale). Conseil de l' Europe, 7, $79 \mathrm{p}$.

GRÜNTHAL, G. ed. 1998. European Macroseismic Scale 1998. Conseil de l' Europe, 15, 99p.

HARDING, T.P. 1985. Seismic characteristics and identification of negative flower structures, positive flower structures and positive structural inversion. Bull. Am. Ass. Petrol. Geol., 69, 582-600.

KAWASE, H. 1996. The cause of the damage belt in Kobe: "The Basin-Edge Effect," constructive interference of the direct S-wave with the basin-induced diffracted/Rayleigh waves. Seismological Research Letters, 67, 2534.

LADE, P. \& COLE, D.Jr. 1984. Influence zones in alluvium over dip-slip faults. J. Geot. Eng., ASCE, 110, May, 599-615.

LEKKAS, E., DANDOULAKI, M., IOANNIDES, K., LALECHOS, $\Sigma$. \& KIRIAZIS, A. 1999. Izmit earthquake, Turkey 1999. Seismotectonic settings - Earthquake and Ground motion characteristics - Geodynamic phenomena - Damage typology and distribution. 13th Hellenic Concrete Conference, Special Issue, Rethimno.

LEKKAS, E. 2000a. Analysis of damage parameters of the Chi-Chi Taiwan earthquake. Risk Analysis II, Ed. Brebbia C.A., Wit Press, 419-432.

LEKKAS, E. 2000b. New data for seismic hazard analysis. Risk Analysis II, Ed. Brebbia C.A., Wit Press, 245255.

MANN, P., HEMPTON, M.R., BRADLEY, D.C. \& BURKE, K. 1983. Development of pull-apart basin. J. Geol., 91, 529-554.

STEIN, R., BARKA, A. \& DIETERICH, H. 1997. Progressive failure on the North Anatolian fault since 1939 by earthquake stress triggering. Geophysical Journal International, 128, 594-604.

STRAUB, C., KAHLE, H.G. \& SCHINDLER, C. 1997. GPS and geological estimates of the tectonic activity in the Marmara Sea region, NW Anatolia. Journal of Geophysical Research, 102, 27587-27601. 